\title{
Tuotantotilojen pintahygienian selvittäminen eri tuotantoympäristöissä
}

\author{
Risto Kuisma'), Hanna-Riitta Kymäläinen ${ }^{1)}$, Marja Lehto ${ }^{2)}$ \\ ${ }^{1)}$ Helsingin yliopisto, Maataloustieteiden osasto, PL 28 (Koetilantie 5), 00014 Helsingin yliopisto \\ risto.kuisma@helsinki.fi,hanna-riitta.kymalainen@helsinki.fi \\ ${ }^{2)}$ Luonnonvarakeskus, Maarintie 6,02150Espoo, marja.lehto@luke.fi
}

\section{TIIVISTELMÄ}

Elintarvikehuoneistossa tuotantotilat on jaettu eri hygienia-alueisiin, ja näiden välistä ristikontaminaatiota tulee välttää. Kuluttajat ja suurkeittiöt haluavat yhä pidemmälle prosessoituja tuotteita. Nämä tuotteet käyvät jatkojalostusprosessissa läpi useita eri käsittelyvaiheita, kuten esimerkiksi pesun, kuorinnan, pilkkomisen, leikkuun, huuhtelun, pakkaamisen tai paistamisen ja savustamisen (kala). Tuotteiden kontaminoituminen voi tapahtua tuotannon kaikissa vaiheissa. Virheelliset toimintatavat voivat edistää tuotteiden pilaantumista ja siirtää tautia aiheuttavia tai tuotetta pilaavia mikrobeja tuotteisiin esimerkiksi henkilöstön, prosessiveden, laitteiden ja koneiden välityksellä. Omavalvonta, jossa hyödynnetään mikrobiologisia menetelmiä, on tärkeä työkalu tuotantoprosessien turvallisuuden hallinnassa. Tutkimuksen tavoitteena oli selvittää erilaisten tuotantotilojen hygieenistä tasoa sekä tunnistaa kriittiset pisteet tuotannossa ja tuotantotiloissa. Tutkimuskohteena olivat kala-, omena-, peruna- ja salaattiyritykset. Tuotantotilojen ja prosessilaitteiden pintojen hygieeninen taso tutkittiin erilaisilla määritysmenetelmillä otetuista pintanäytteistä. Näytteet otettiin yrityksessä käytetyn tavanomaisen puhdistuksen jälkeen. Aerobisten mikrobien, enterobakteerien ja ß-glukuronidaasi-entsyymejä tuottavien lajien sekä hiivojen ja homeiden kokonaismäärän määritykseen käytettiin muun muassa Hygicult@-kontaktilevyjä. Kasviksia käsittelevien laitosten pinnoilta mitattiin korkeita mikrobipitoisuuksia kun niitä verrataan suomalaisessa pintahygieniaoppaassa esitettyihin yleisiin viitearvoihin. Tulosten arvioinnissa tulee kuitenkin ottaa huomioon eri tuotantolaitosten tyypit ja tuotannon vaiheet. Tutkimuksen jälkeen yritysten johtoa opastettiin kiinnittämään aiempaa enemmän huomiota laitoksen puhtaanapitoon, tuotantoalueiden suunnitteluun, työntekijöiden koulutukseen ja omavalvontaan. Kokonaisuutena tulokset osoittivat, että monissa kasvisten tuotantoyrityksissä on selkeä tarve parantaa puhdistus- ja hygieniakäytäntöjä. Kalaa käsittelevän yrityksen pintahygieniatulokset olivat pääsääntöisesti erinomaisella tasolla.

Tutkimus tehtiin "Uutta liiketoimintaa sivutuotteista (Uusivu)" -hankkeessa, jossa kehitetään kasvis-, liha- ja kalayritysten sivutuotteiden hyödyntämistä ja käsittelyä. Käsittelyketjua tarkastellaan kestävän kehityksen tarpeiden pohjalta. Uusivu-hanke on alueiden välinen Manner-Suomen maaseudun kehittämishanke ja sitä toteuttavat Luonnonvarakeskus Luke ja Helsingin yliopisto sekä yritykset. Hanketta rahoittavat Uudenmaan, Kaakkois-Suomen, Varsinais-Suomen, Etelä- ja Pohjois-Savon, Hämeen ja Pirkanmaan ELY-keskukset sekä yritykset. Hanke alkoi vuoden 2017 alussa ja se kestää vuoden 2020 kesäkuun loppuun.

Asiasanat: hygieniakartoitus, hygienia, mittaaminen, omavalvonta 


\section{Johdanto}

Elintarvikkeita käsittelevien yritysten pintahygienialla on suuri merkitys raaka-aineiden ja tuotteiden mikrobiologisen laadun kannalta. Mitä puhtaampia prosessit ovat, sitä vähemmän syntyy hävikkiä, ja puhtaat sivujakeet voidaan hyödyntää edelleen. Tässä tutkimuksessa tarkasteltiin kalaa, perunaa, omenaa ja salaattia prosessoivien yritysten tuotantotilojen hygieenistä tasoa.

Suurin osa elintarvikevälitteisistä sairauksista johtuu raaka-aineiden huonosta laadusta ja tuotantolaitosten prosesseista, mutta merkittävä osuus voi olla seurausta myös elintarvikkeiden valmistajien ja vähittäiskauppiaiden epähygieenisistä toimintavoista (Ismaïl ym. 2013). Työympäristön, erityisesti elintarvikkeiden kanssa kosketuksissa olevien pintojen, laitteiden ja koneiden korkea hygieniataso, on perusedellytys turvallisten elintarvikkeiden valmistukselle (Osimani ym. 2014).

Useat taudinaiheuttajat, mukaan lukien Staphylococcus aureus, Listeria monocytogenes, Salmonella spp. ja enteropatogeeniset Escherichia coli -kannat voivat säilyä eri pinnoilla useista tunneista päiviin ja muodostaa biofilmin (Martinon ym. 2012). Käsittelyvaiheet, kuten pesu tai desinfiointi, leikkaaminen ja varastointi, tarjoavat monia mahdollisuuksia elintarvikkeiden ja niiden raaka-aineiden ristikontaminaatioon (Matthews ym. 2014). Elintarvikkeiden kanssa kosketukseen joutuvat pinnat, mukaan lukien laitteet, työkalut, astiat ja lisävarusteet, joita käytetään lukuisissa kasvisten varastointi-, lajittelu- ja käsittelyvaiheissa, voivat osaltaan edistää taudinaiheuttajien aiheuttamaa ristikontaminaatiota. Esimerkiksi E. coli O157:H7:n on todettu siirtyneen laitteiden pinnalta tuoreisiin pilkottuihin lehtivihanneksiin prosessoinnin aikana (Buchholz ym. 2012). Muun muassa metalliset pinnat on tunnistettu patogeenisen ristikontaminaation edistäjiksi tuoretuotteissa (Kusumaningrum ym. 2003, Ryu ja Beuchat 2005, Axelsson ym. 2013).

Biofilmin muodostuminen alkaa elintarvikkeita prosessoivissa yrityksissä yleensä, kun puhdistus- ja hygieniatoimenpiteitä ei tehdä oikein (Srey ym. 2013). Elintarvikkeiden kanssa kosketuksiin joutuvien pintojen riittämätön puhdistus ja desinfiointi voi johtaa paitsi tuotteen säilyvyysajan lyhentymiseen, myös tautia aiheuttavien mikrobien lisääntymiseen (Moore ym. 2002). Elintarvikkeiden kanssa kosketuksiin joutuvien pintojen mikrobiologisen turvallisuuden parantamiseksi on kehitetty monipuolisia, tehokkaita desinfiointimenetelmiä (Duncan 2011, Llorens ym. 2012).

Toisin kuin elintarvikkeille, joille mikrobiologiset kriteerit on vahvistettu Euroopan unionissa asetuksella (EY N:o 2073/2005) ja sen myöhemmillä muutoksilla, elintarviketeollisuudessa käytettävien pintojen ja laitteiden puhtaudelle ei ole lain määräämiä vaatimuksia. Elintarvikealan toimijoilla on velvollisuus määritellä, toteuttaa ja valvoa tuotantotilojensa asianmukaista puhdistus- ja puhtaanapitoohjelmaa asetuksen (EY) N:o 852/2004 (EY 2004) mukaisesti. Tämän asetuksen yleisiin vaatimuksiin sisältyy muun muassa kaikkien elintarvikkeiden tuotantotilojen puhtaanapito. Elintarvikkeiden kanssa kosketuksiin joutuvat pinnat tulee voida puhdistaa ja desinfioida helposti. Monet yritykset ovat laajentaneet tuotantoaan alkutuotannosta jatkojalostukseen (esimerkiksi juuresten kuorinta, kasvisten pilkonta), mikä lisää merkittävästi tiedon ja osaamisen tarvetta yrityksissä lainsäädännön vaatimusten vuoksi. Hyvä pintahygienia on erittäin tärkeää maataloustuotteita jatkojalostavissa yrityksissä, jotta taataan tuotteiden elintarviketurvallisuus.

Tämän tutkimuksen hygieniakartoitusten tavoitteena oli tutkia jatkojalostusyritysten valittujen tuotantotilojen pintojen puhtaustasoa. Kartoituksien tulosten pohjalta yrityksissä voidaan kiinnittää huomiota epäkohtiin sekä tehostaa ongelmallisten pintojen puhtaanapitoa ja omavalvontaa sekä muita pintojen puhtauteen vaikuttavia käytäntöjä.

\section{Aineisto ja menetelmät}

Hygieniakartoitukset tehtiin loppuvuonna 2018 ja alkuvuodesta 2019 kolmessa kasvisalan yrityksessä ja yhdessä kalaa prosessoivassa yrityksessä. Jatkojalostusyritykset poikkesivat toisistaan huomattavasti toimintojensa ja prosessiensa suhteen. Mukana oli yrityksiä, jotka sekä tuottavat raaka-aineen että prosessoivat sen valmiiksi tuotteiksi, sekä pelkästään esikäsiteltyä raaka-ainetta jatkojalostavia yrityksiä. Tutkimuksen toteutus oli pääpiirteissään aiempien tutkimusten (Lehto ym. 2011, Kuisma ym. 2016) kaltainen, mutta tutkittavat yritykset poikkesivat aiemmin tutkituista. 
Yrityksissä tehtiin ennen hygieniakartoitusta esikartoituskäynnit, joiden pohjalta laadittiin kirjalliset, valokuvin varustetut näytteenottosuunnitelmat mitattavista kohteista. Kunkin yrityksen edustajat nimesivät kartoitukseensa sisällytettävät huonetilat. Hygieniakartoitukset toteutettiin näytteenottosuunnitelmien mukaisesti, ottaen huomioon kohteen yksilölliset piirteet näytteenottotilanteessa. Kartoituksissa keskityttiin mahdollisiin tuotteen mikrobiologisen laadun kannalta kriittisiin näytteenottokohtiin ja pintoihin; tällaisia olivat esimerkiksi katkaisijat, koneet ja laitteet, altaat, työtasot ja siivousvälineet.

Pintanäytteet otettiin esikartoituskäyntien perusteella valituista näytteenottopisteistä käyttäen Orion Diagnostican Hygicult ${ }^{\circledR}$-kontaktilevyjä, jotka mittaavat aerobisten mikrobien kokonaismäärää (TPC), enterobakteerien ja ß-glukuronidaasi-entsyymejä tuottavien lajien kokonaismäärää (E/ß-Gur) sekä hiivojen ja homeiden kokonaismäärää (Y\&F). Pintapuhtausnäytteitä otettiin myös ATPbioluminesenssimääritystä varten (ATP=adenosiini-trifosfaatti). Nämä näytteet otettiin vanupuikolla reagenssiputkeen, jonka kyvetistä mitattiin välittömästi ATP-bioluminesenssi luminometrisesti Hygiena EnSURE -laitteella. Syntyneen valon intensiteetti luettiin näytöltä suhteellisina valoyksikköinä RLU (relative light units). RLU on suoraan verrannollinen ATP:n ja siten biologisen aineksen aiheuttaman kontaminaation määrään. Näytteenotot suoritettiin detektiovälineiden valmistajien ohjeiden mukaisesti. Tulosten tulkinnassa käytetyt raja-arvot ja viitteet tulosten luokittelemiseksi on esitetty Lehdon ym. (2011) artikkelissa.

Tulokset koottiin Excel-tietokantaan ja jaettiin mittauskohteittain viiteen ryhmään aiempien tutkimusten (Lehto ym. 2011, Kuisma ym. 2016) mukaisesti. Tutkitut pinnat olivat suoraan kosketuksessa tuotteeseen ryhmissä 1 ja 2 sekä osittain ryhmässä 3 .

1) Koneiden pinnat, kuten leikkurit, kuorintakoneet jne.

2) Tuotteen kanssa kosketuksissa olevat muut pinnat kuin koneet, mukaan lukien muun muassa erilaiset pöydänpinnat, leikkuulaudat ja veitset

3) Kuljetinhihnat

4) Pakkaukset

5) Pinnat, jotka eivät ole suorassa kosketuksessa tuotteiden kanssa: esim. ohjauspaneelit ja muut sisäympäristön pinnat, kuten ovien kahvat, näytöt, vaa'at, lattiat ja siivousvälineet

Mittauspisteiden lukumäärät ilmenevät Taulukosta 1. Yrityksessä B ei ollut mittauskohteina kuljetinhihnoja ja pakkauksia, yrityksessä D ei puolestaan ollut pakkauksia.

Taulukko 1. Mittauspisteiden lukumäärät (n) eri mittauskohteissa ja yrityksissä A-D.

\begin{tabular}{|c|c|c|c|c|c|c|c|c|c|c|c|c|c|c|c|c|}
\hline \multirow[t]{2}{*}{ Mittauskohde } & \multicolumn{5}{|c|}{ Kokonaismikrobit } & \multicolumn{3}{|c|}{ Hiivat } & \multicolumn{4}{|c|}{ Enterobakteerit ja $\beta$-Gur } & \multicolumn{4}{|c|}{$\begin{array}{c}\text { ATP- } \\
\text { bioluminesenssi }\end{array}$} \\
\hline & $\bar{A}$ & $\mathrm{~B}$ & $\mathrm{C}$ & $\mathrm{D}$ & $\mathrm{A}$ & $\mathrm{B}$ & $\mathrm{C}$ & $\mathrm{D}$ & $\mathrm{A}$ & $\mathrm{B}$ & $\mathrm{C}$ & $\mathrm{D}$ & A & B & $\mathrm{C}$ & $\mathrm{D}$ \\
\hline $\begin{array}{l}\text { Koneet: leikkurit, kuorimet } \\
\text { ym. }\end{array}$ & 4 & 8 & 4 & 10 & 4 & 8 & 4 & 10 & 2 & 4 & 2 & 5 & 2 & 2 & 2 & 1 \\
\hline $\begin{array}{l}\text { Tuotteen kanssa } \\
\text { kosketuksissa olevat pinnat }\end{array}$ & 60 & 9 & 28 & 22 & 58 & 9 & 28 & 22 & 29 & 5 & 14 & 11 & 16 & 5 & 5 & 2 \\
\hline Kuljetinhihnat & 10 & 0 & 16 & 28 & 10 & 0 & 16 & 28 & 5 & 0 & 7 & 14 & 0 & 0 & 5 & 6 \\
\hline Pakkaukset & 2 & 0 & 10 & 0 & 2 & 0 & 10 & 0 & 1 & 0 & 5 & 0 & 0 & 0 & 0 & 0 \\
\hline $\begin{array}{l}\text { Ei suoraan tuotteen kanssa } \\
\text { kosketuksissa olevat pinnat }\end{array}$ & 22 & 22 & 64 & 28 & 6 & 22 & 10 & 16 & 9 & 11 & 26 & 13 & 0 & 0 & 0 & 0 \\
\hline Yhteensä & 98 & 39 & 122 & 88 & 39 & 39 & 68 & 76 & 46 & 20 & 54 & 43 & 18 & 7 & 12 & 9 \\
\hline
\end{tabular}




\section{Tulokset ja tulosten tarkastelu}

Hygieniakartoitusten tulosten perusteella hygieniataso vaihteli suuresti yritysten välillä (Kuva 1). Kalayrityksen (A) mikrobiologiset tulokset olivat erinomaisella tasolla. Korkeimmat keskimääräiset mikrobimäärät mitattiin kasvisyrityksestä D.

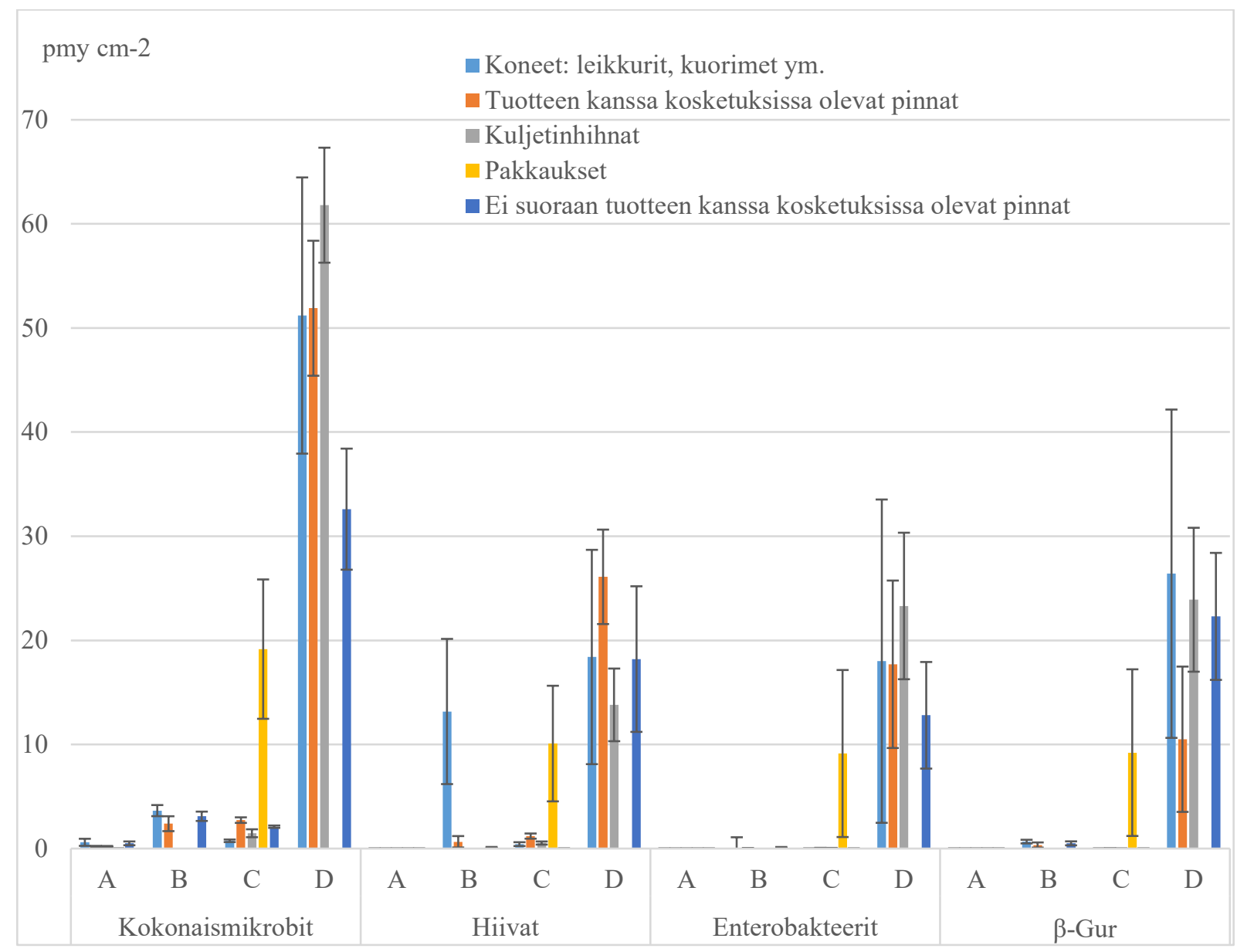

Kuva 1. Yrityskohtaiset mikrobiologiset pintanäytetulokset. A = kalayritys, B-D = kasvisyritykset.

ATP-bioluminenssimittauksia tehtiin valikoiduista muista mittauspisteistä, mutta ei suoraan tuotteen kanssa kosketuksissa olevilta pinnoilta ja pakkausten pinnoilta. Tietyn mittauskohteen tulosten vaihteluvälit olivat yrityksen A leikkureita ja koneita lukuun ottamatta suuret (Taulukko 2).

Taulukko 2. Tutkittujen yritysten pintahygieniatulokset: ATP-bioluminesenssi.

\begin{tabular}{lllll}
\hline Yritys & Mittauskohde (n) & \multicolumn{2}{l}{ ATP-arvot (RLU) } \\
\cline { 3 - 5 } & & Vaihteluväli & Keskiarvo $\begin{array}{l}\text { Keskiarvon } \\
\text { keskivirhe }\end{array}$ \\
\hline Kalayritys (A) & Tuotteen kanssa kosketuksissa olevat pinnat (16) & $0 \ldots .2300$ & 161 & 143 \\
& Leikkurit ja koneet (2) & $0 \ldots 133$ & 65 & 65 \\
Kasvisyritykset & Kuljettimen hihnat (11) & $11 \ldots>9999$ & 4143 & 1379 \\
(B-D) & Tuotteen kanssa kosketuksissa olevat pinnat (12) & $4 \ldots 7798$ & 1367 & 857 \\
& Leikkurit ja koneet (5) & $13 \ldots .7393$ & 1696 & 1430 \\
\hline
\end{tabular}


Elintarviketeollisuuden puhtaanapidossa tulee kiinnittää erityistä huomiota yleiseen hygieniatasoon sekä puhdistus- ja desinfiointimenetelmiin. Tämän tutkimuksen tulosten perusteella haasteita on erityisesti kasvisyrityksissä.

Kalaa käsittelevän yrityksen pintapuhtaustulokset olivat hyvällä tasolla. Kalateollisuuden ongelmakohdat tuotantohygienian näkökulmasta ovat hankalasti purettavat ja puhdistettavat laitteet, esimerkiksi nahanpoisto-, fileointi ja suolauslaitteet, sillä niihin jää helposti tuotejäämiä, jotka ovat hyviä kasvupaikkoja monille bakteereille (Wirtanen 2002). Listeria monocytogenes bakteerikontaminaatio on merkittävä riski prosessoiduille kalatuotteille (Aalto-Araneda ym. 2019), mikä vuoksi korkea hygieniataso on erityisen tärkeä kaikissa kalan käsittelyn vaiheissa.

Hygieniakartoituksien tulosten perusteella ongelmallisimmiksi kohteiksi osoittautuivat kuljettimet ja muut tuotteiden kanssa kosketuksissa olevat pinnat. Yleisin syy ongelmallisimpien elintarviketuotannon laitteiden hygieniaongelmiin on kirjallisuuden mukaan huono hygieeninen suunnittelu. Huono laite- ja tilasuunnittelu johtaa tarpeeseen lisätä puhdistuksen taajuutta ja kestoa sekä käyttää voimakkaita kemikaaleja (Lelieveld ym. 2003). Laitteen rakenne voi esimerkiksi lisätä orgaanisen aineksen kertymistä laitteen pinnoille ja hankaloittaa puhdistusta. VTT Biotekniikan ja Helsingin yliopiston eläinlääketieteellisen tiedekunnan elintarvike- ja ympäristöhygienian laitoksen projektissa "Hygieeniset laitteet elintarviketeollisuudessa" ongelmallisimmiksi laitteiksi hygienian ja puhdistamisen kannalta havaittiin pakkauskoneet, kuljettimet, annostelukoneet, jäḧhdyttimet ja siivutuskoneet (Wirtanen 2002). Pakkaaminen on viimeinen vaihe ennen tuotteen kuljettamista jälleenmyyjille ja kuluttajille, ja tuotteen säilyvyys riippuu suuressa määrin asianmukaisesta pakkauksesta.

Myös tuotteiden kanssa epäsuorassa kosketuksessa olevat pinnat voivat välittää kontaminaatiota tuotteisiin, mikä on ongelma erityisesti korkean hygienian alueella (Lehto ym. 2013). Korkean hygienian alue tarkoittaa aluetta, jolla on korkein puhtausvaatimus. Alueella käsitellään tai säilytetään suojaamattomia tuotteita, ja tuotteiden käsittelyltä edellytetään erityisen hygieenistä työjärjestystä (Kuisma ym. 2012).

Tuotantotiloissa tulee olla kunnolliset puhdistus- ja omavalvontasuunnitelmat (Kuisma ym. 2012) ja niitä tulee noudattaa. Lisäksi esimerkiksi uusimalla kuljetinhihnoja ja leikkuulautoja, ottamalla käyttöön kenkien puhdistusjärjestelmiä eri hygienia-alueiden välillä sekä käyttämällä automaattihanoja voidaan osaltaan parantaa pintahygieniaa.

Kuisman ym. (2016) vuosina 2009 ja 2012 kasvisyrityksissä tekemissä hygieniakartoitustutkimuksissa ongelmallisimmiksi pinnoiksi osoittautuivat koneet ja laitteet sekä kuljettimien hihnat. Myös nyt tehdyissä hygieniakartoituksissa saatiin samankaltaisia tuloksia. Edellä mainitut pinnat on todettu tuotantohygienian kannalta mikrobiologiseksi vaaratekijäksi, joten näiden pintojen puhdistukseen tulee lisätä resursseja. Kasvistuotantolaitoksien on tarpeen kehittää puhdistus- ja hygieniakäytäntöjään edelleen, ja lisäksi työntekijöiden koulutusta ja pintojen omavalvontaa olisi lisättävä. Hyvän tuotantohygienian saavuttamiseksi tuorekasviksia pilkkoville yrityksille on laadittu hyvän käytännön ohje (Lehto ym. 2015). Puhtaanapidon perusasioita on käsitelty kasvisalalle suunnatussa puhtausoppaassa (Kuisma ym. 2012).

\section{Johtopäätökset}

Elintarvikkeita prosessoivien yritysten tulee kiinnittää puhtaanapidossa erityistä huomiota omavalvontaan, yleiseen hygieniatasoon sekä puhdistus- ja desinfiointimenetelmiin. Käsittelytilojentilojen ja -välineiden siisteydellä ja eheydellä on suuri merkitys yleisen ja tuotehygienian kannalta. Kuluneet pinnat ovat hyviä kasvualustoja mikrobeille, sillä niiden siivoaminen on epätasaisen pinnan vuoksi vaikeaa. Tässä tutkimuksessa kalankäsittelytilojen puhtaustaso ja tutkittavat pinnat olivat erinomaiset. Kasviksia prosessoivien yritysten B ja C pintahygienia oli pääosin hyvällä tasolla, mutta näissäkin yrityksissä pesu- ja puhdistusprosesseja on tarpeen parantaa. Kasvisyrityksen D tulee tehostaa pesuprosessia ja lisätä pintapuhtauden seurantaa, jotta pintahygienia saadaan paremmalle tasolle. Tämä tutkimus vahvisti aiemmissa tutkimuksissa tehtyjä havaintoja siitä, että tuotantotilojen pintojen puhdistettavuuteen sekä tuotantotilojen säännölliseen ja perusteelliseen puhdistukseen sekä 
desinfiointiin tulee kiinnittää erityistä huomiota. Varsinkin kuljetinhihnat ja laitteet ovat usein kriittisiä kohteita likaantumisen ehkäisyn ja puhdistamisen kannalta. Puhtaanapito ja sen seuraaminen ovat jatkuva prosessi, jota tulee kehittää koko ajan.

\section{Kiitokset}

Kiitämme tutkimukseen osallistuneita yrityksiä yhteistyöstä. Tutkimus kuuluu hankkeeseen "Uutta liiketoimintaa sivutuotteista" (Uusivu), jota rahoittavat Uudenmaan, Kaakkois-Suomen, VarsinaisSuomen, Etelä- ja Pohjois-Savon, Hämeen ja Pirkanmaan ELY-keskukset sekä yritykset.

\section{Kirjallisuus}

Aalto-Araneda, M., Lundén, J., Markkula, A., Hakola, S. \& Korkeala, H. 2019. Processing plant and machinery sanitation and hygiene practices associate with Listeria monocytogenes occurrence in ready-to-eat fish products. Food Microbiology 82: 455-464. https://doi.org/10.1016/j.fm.2019.03.017

Axelsson, L., Holck, A., Rud, I., Samah, D., Tierce, P., Favre, M. \& Kure, C.F. 2013. Cleaning of conveyor belt materials using ultrasound in a thin layer of water. Journal of Food Protection 76: 1401-1407.

https://doi.org/10.4315/0362-028X.JFP-12-563

Buchholz, A.L., Davidson, G.R., Marks, B.P., Todd, E. C.D. \& Ryser, E.T. 2012. Quantitative transfer of Escherichia coli O157: $\mathrm{H} 7$ to equipment during small-scale production of fresh-cut leafy greens. Journal of Food Protection 75: 1184-1197. https://doi.org/10.4315/0362-028X.JFP-11-489

Duncan, T.V. 2011. Applications of nanotechnology in food packaging and food safety: Barrier materials, antimicrobials and sensors. Journal of Colloid and Interface Science 363: 1-24.

https://doi.org/10.1016/j.jcis.2011.07.017

EC, 2004. Regulation (EC) No 852/2004 of the European parliament and of the council of 29 April 2004 on the hygiene of foodstuffs. Official Journal of the European Union, L, 226: 1-23.

https://www.fsai.ie/uploadedFiles/Consol_Reg852_2004.pdf

EC, 2005. Commission Regulation (EC) No 2073/2005 of 15 November 2005 on microbiological criteria for foodstuffs. Official Journal of the European Union, L, 338: 1-26. http://data.europa.eu/eli/reg/2005/2073/oj Ismail, R., Aviat, F., Michel, V., Le Bayon, I., Gay-Perret, P., Kutnik, M. \& Federighi, M. 2013. Methods for Recovering Microorganisms from Solid Surfaces Used in the Food Industry: A Review of the Literature. International Journal of Environmental Research and Public Health 10: 6169-6183.

https://doi.org/10.3390/ijerph10116169

Kuisma, R., Pienmunne, E., Lehto, M., Mäki, M. \& Kymäläinen, H.-R. 2012. Puhtausopas tuorevihannesten tuotantolaitoksille. Helsingin yliopisto, Maataloustieteiden laitoksen julkaisuja 11/2012. $58 \mathrm{~s}$.

http://hdl.handle.net/10138/36024

Kusumaningrum, H. Riboldi, G., Hazeleger, W.C. \& Beumer, R.R. 2003. Survival of foodborne pathogens on stainless steel surfaces and cross-contamination to foods. International Journal of Food Microbiology 85: 227 236. https://doi.org/10.1016/S0168-1605(02)00540-8

Lieveld, H.L.M, Mostert, M.A. \& Curiel, G.J. 2003. Hygienic equipment design. In Lelieveld H.L.M. Holah, J.T \& Napper, D. (eds). Hygiene in food processing, Woodhead Publishing, Cambridge. s. 122-166.

Kuisma, R.M.J., Kymäläinen, H.-R. \& Lehto, M., 2016. Tuorevihannesten tuotantotilojen pintahygienian selvittäminen. Suomen Maataloustieteellisen Seuran Tiedote 33. https://doi.org/10.33354/smst.75148

Lehto, M., Kuisma, R., Kymäläinen, H.-R., Suojala-Ahlfors, T., Laamanen, T.-L., Sipilä, I., Pienmunne, E. \& Mäki, M. 2013. Tuorevihannesten tuotantoketjun tavoitteena turvallinen tuote. MTT raportti 86. $63 \mathrm{~s}$. http://Www.mtt.fi/mttraportti/PDF/mttraportti86.pdf

Lehto, M., Kuisma, R., Määttä, J., Kymäläinen, H.-R. \& Mäki, M. 2011. Hygienic level and surface contamination in fresh-cut vegetable production plants. Food Control 22: 469-475.

https://doi.org/10.1016/j.foodcont.2010.09.029

Lehto, M., Mäki, M., Kuisma, R. \& Kymäläinen, H.-R. 2015. Hyvän käytännön ohje tuorekasviksia pilkkoville yrityksille. Luonnonvara- ja biotalouden tutkimus 10/2015, Luonnonvarakeskus (Luke). 129 s.

http://urn.fi/URN:ISBN:978-952-326-09-2. 
Llorens, A., Lloret, E., Picouet, P.A., Trbojevich, R. \& Fernandez, A. 2012. Metallic-based micro and nanocomposites in food contact materials and active food packaging. Trends in Food Science \& Technology 24: 19-29. https://doi.org/10.1016/j.tifs.2011.10.001

Matthews, K.R., Sapers, G.M. \& Gerba, C.P. 2014. The produce contamination problem. Elsevier. 492 s. https://doi.org/10.1016/C2012-0-01380-4

Martinon, A., Cronin, U.P., Quealy, J., Stapleton, A. \& Wilkinson, M.G. 2012. Swab sample preparation and viable real-time PCR methodologies for the recovery of Escherichia coli, Staphylococcus aureus or Listeria monocytogenes from artificially contaminated food processing surfaces. Food Control 24: 86-94.

https://doi.org/10.1016/j.foodcont.2011.09.007

Osimani, A., Garofalo, C., Clementi, F., Tavoletti, S. \& Aquilanti, L. 2014. Bioluminescence ATP monitoring for the routine assessment of food contact surface cleanliness in a university canteen. International Journal of Environmental Research and Public Health 11: 10824-10837. https://doi.org/10.3390/ijerph111010824

Ryu, J.-H. \& Beuchat, L.R. 2005. Biofilm formation and sporulation by Bacillus cereus on a stainless steel surface and subsequent resistance of vegetative cells and spores to chlorine, chlorine dioxide, and a peroxyacetic acid-based sanitizer. Journal of Food Protection 68: 2614-2622.

https://jfoodprotection.org/doi/pdf/10.4315/0362-028X-68.12.2614

Srey, S., Jahid, I.K. \& Ha, S.A. 2013. Biofilm formation in food industries: A food safety concern. Food Control 31: 572-585. https://doi.org/10.1016/j.foodcont.2012.12.001

Wirtanen, G. 2002. Laitehygienia elintarviketeollisuudessa: hygieniaongelmien ja Listeria monocytogeneksen hallintakeinot. Valtion teknillinen tutkimuslaitos VTT. $187 \mathrm{~s}$.

http://www.vtt.fi/inf/pdf/publications/2002/P480.pdf 